\title{
Food self-provisioning motivations revisited: Czech home gardens and their food production
}

\author{
JANA ŠIFTOVÁ
}

Charles University, Faculty of Science, Department of Social Geography and Regional Development, Prague, Czechia; e-mail: jana.siftova@natur.cuni.cz

ABSTRACT This paper revisits the motivations and behaviours related to home food production in private home gardens. It aims to answer these research questions: (i) which activities are performed in the home garden?; (ii) if the garden fulfils the self-provisioning function, what are the motivations for food production?; (iii) does gardening and food self-provisioning impact a household's environmental behaviour?; and (iv) does food self-provisioning relate to a household's economic situation? The results show that production of vegetables and herbs is still the prevailing function of Czech home gardens. The motivations for this activity are better taste, healthier way of production and enjoyment of gardening as a hobby. These motivations remain mostly intact during societal transformations or economy fluctuations over recent decades, which declares the strength and tradition of home food production in Czechia. Economic motivation was not proved as an important motivation. There was evidence for some kinds of pro-environment behaviour, however, this is limited to rather inconspicuous, private actions.

KEY WORDS home gardens - food self-provisioning - motivations - environmental behaviour economic situation - Czechia

ŠIFTOVÁ, J. (2021): Food self-provisioning motivations revisited: Czech home gardens and their food production. Geografie, 126, 2, 149-167.

https://doi.org/10.37040/geografie.2021.002

Received January 2021, accepted March 2021.

CC Česká geografická společnost, z. s., 2021 


\section{Introduction}

Gardening is, without doubt, a traditional Czech leisure activity. The roots of the urban gardening tradition reach back to the industrial revolution, when people moving from the country to the cities longed for a piece of land to cultivate. Gardeners' organizations emerged in the second half of the $19^{\text {th }}$ century, together with the tradition of gardeners' exhibitions. The first allotment gardens in Czechia date back to 1906 (Jankovičová 2017) and, during the economic crisis in the thirties of the $20^{\text {th }}$ century, gardens helped to secure many poverty-stricken households with their own produce. It was, however, during the socialist era when gardening in Czechia became a real phenomenon. It represented one of the scarce possibilities for leisure activity supported by the communist regime and a valuable recreation opportunity in a time when foreign travel was limited (Macl 1999, 2002). The revolution year of 1989 and subsequent new choices brought a decline of interest in gardening, especially in its organised form (Spilková, Vágner 2018). However, it seems that nowadays many people are returning to gardening as a meaningful activity to fight the stresses of the modern urban and work life and to reconnect with nature. This brings, of course, a lot of new stimuli for the reconsideration of urban planning, especially in the realm of sustainable urban food systems and conflicting land use in the urban areas (Spilková, Vágner 2016), policy formulation (Vávra, Daněk, Jehlička 2018; Vávra, Smutná, Hruška 2021) or in the area of neighbourhood organization and community resilience (Spilková 2017; Jehlička, Daněk, Vávra 2019; Spilková, Rypáčková 2019).

It thus comes as no surprise that gardening, and food self-provisioning in particular, became a frequent topic of research among the Czech geographers and social scientists during the last decade. Allotment gardens, as traditional forms of urban gardening, received early scholar attention when Gibas et al. (2013) published a monograph on allotment garden colonies and their historical and current perception. Sovová (2015) made a valuable attempt to quantify the home production of gardeners in Brno with the use of food logs in her research, revealing huge differences in produce even within a single gardening locality. Spilková and Vágner (2016) warned against the urbanisation pressures affecting allotment garden colonies in Prague and assessed the future of gardens as important elements of urban agriculture (Spilková, Vágner 2018). Community gardens, as a rather recent phenomenon, appeared in the spotlight of research endeavour slightly later. Spilková (2017) described the phenomenon of emerging community gardens and this new form of gardening in Czech cities and later considered this type of gardening activity within the framework of liquid leisure (Spilková, Rypáčková 2019). Drivers vital for members of community gardens in Czechia were studied recently also by Dubová, Macháč and Vacková (2020). All the works on emerging community gardens in Czechia basically come to an 
agreement - the community is more of a priority than the gardening itself, food production or other benefits.

Smith and Jehlička (2013) sparked their long-lasting interest in the issue of food self-provisioning and sharing. In their subsequent works, they questioned also motivations of food self-provisioning and sharing in Central and Eastern European (CEE) countries. In Jehlička, Kostelecký and Smith (2013), they opposed the "western" vision of CEE gardening as a subsistence activity in poverty and economic crisis. Jehlička and Daněk (2017) focused on sharing of the home produced food, sharing networks and their organization and flows. Vávra et al. (2018) analysed food self-provisioning in a comparative study of sociodemographic factors behind food self-provisioning in five European countries revealing individual differences between the countries (Scotland, Netherlands, Germany, Czechia and Hungary), between the "East" and "West", but, on the other hand, also some similarities (access to garden, higher age, lower economic status etc.) Sovová and Veen (2020) compared the practice and motivation of Czech and Dutch gardeners, stating that there are more differences within the particular groups of gardeners than between gardeners from these two countries. In a recent study, Vávra, Smutná and Hruška (2021) turn to food self-provisioning in rural Czechia, sharing and the relation between gardening and rural landscape. Vávra, Daněk and Jehlička (2018) also authored an interesting study of food self-provisioning in relation to the environment, mainly greenhouse gas emissions.

One issue, which recurs repeatedly within these works, is thus the question of food self-provisioning motivations. There are two aspects in particular, which generate many discussions - the environmental motivation and the economic motivation of Czech gardeners. Whereas most authors deny environmental motivation of Czech gardeners and food self-provisioners (Jehlička, Kostelecký, Smith 2013; Vávra, Daněk, Jehlička 2018) and admit only unintentional interest in sustainable practices from Czech gardeners (so called "quiet sustainability"), economic motivation reveals more contrasting views. Sovová and Veen (2020) and Jehlička, Kostelecký, and Smith (2013) report that there are almost no economic motivations within their samples and the lowest income groups usually do not participate overly in food self-provisioning compared to the better-off. Nevertheless, Vávra et al. (2018) revealed that economic motivation could be relevant, since the lowest income group in their research shows a higher probability of food self-provisioning than the highest income groups. There are thus some conflicting views in the extant literature, which warrants a fresh look on this topic. This paper revisits the issue of motivations for home food production by applying some of the tools inspired by foreign surveys (Dunnett, Quasim 2000; Schupp, Sharp 2012), especially in the economic and environmental aspects of home food self-provisioning. It focuses on private home gardens. The home garden in this paper is defined as the area of parcel minus the area of the house (Loram, 
Warren, Gaston 2008); "private" in this research includes both ownership and rental gardens.

\section{Motivations for food self-provisioning in home gardens}

Motivations for home food production are highly diverse as works of both Czech and foreign scholars document. There is a number of works focusing on the reason why people produce their own food. Zainuddin and Mercer (2014) sum up the motivations for engaging in backyard production in Melbourne, Australia, into five categories: health and nutrition; ecology and environment; food security and selfreliance; cost; and pleasure and enjoyment. Kirkpatrick and Davison (2018, p. 28) state that the following motivations were expressed by more than half of their respondents in Tasmania: vegetable gardening is a pleasure; home grown produce tastes better; growing vegetables is good for the health of the gardener; growing vegetables is a family tradition; and home grown produce has more nutrients. Kirkpatrick and Davison found no socio-economic or demographic differentiation between motivational groups, which might indicate that stimuli and social values related to home food self-provisioning do not align with conventional social divisions, such as those based on wealth, education, and housing tenure.

McClintock et al. (2016) mention similar motivations - freshness, eating healthily, having nutritious produce, living in an environmentally sustainable way, relaxing and being more self-sufficient for residential gardeners in Oregon, USA. However, in their study, many of these motivations differed along income, educational, class, and geographic lines. Nevertheless, also in this study, $97 \%$ of respondents reported that earning money was not at all a reason for growing food in home gardens (McClintock et al. 2016, p. 10). Larder, Lyons and Woolcock (2014) divided the values and beliefs of backyard gardeners in their research in Brisbane, Australia, into four groups: ability to choose where food came from and where it was grown; sustainability and connection to earth and place; community building (including exchange of knowledge among neighbours); and culture and tradition (way of growing up, familial interaction, etc.). Smith and Jehlička (2013) mention fresh and healthy food as a primary motivation for Czech (and Polish) gardeners. Sovová and Veen (2020) state that the most important motivation for their Czech respondents was that they enjoy gardening as a hobby.

There are also works which aimed to create a typology of gardens or gardeners. Kotright and Wakefield (2011), based on their research in Toronto, Canada, discern between cook's gardens (practical, aimed at fresh produce), teaching gardens (cultivated mainly for children as a teaching opportunity), environmental gardens (tended with the intention of reducing ecological footprint), hobby gardens (for pleasure from planting), and aesthetic gardens (food is just a bonus, 
the goal is plants). Kirkpatrick and Davison (2018) discriminated five vegetable garden types, mostly based on the variation of food produced: traditional; staple; salad and herb; complex; tomato and parsley. Similarly, they created five types of vegetable gardeners, based on their motivations - activists, spenders, healthproviders, stewards, and economisers.

From this literature review, it is obvious that the reasons and motivations for home food production and gardening are mostly the same across the global North. There might be slight differences in individual rankings of the motives and selfperceived importance ascribed to particular reasons, but in general, the motivations and values strongly resonate. As Sovová and Veen (2020, p. 2) acknowledge, Western Europe and the Global North in general present "a diffuse but mostly positive and progressive picture of food-self provisioning". The way the Global South and its story of home food production is pictured is different - mostly economically motivated, aimed at food security and/or food sovereignty, often with cultural motivations highlighted (Schupp, Sharp 2012). Within these debates, Central and Eastern Europe often seems an excluded space or place somewhere "in between". Home food production is viewed as a remnant of the socialist era and described through the terms of the shortage economy (Alber, Kohler 2008; Smith, Jehlička 2013 etc.). As Sovová and Veen (2020, p. 3) argue "examples of food self-provisioning in CEE are accompanied by a specific framing which distinguishes them from their Western European counterparts". Recently, many interesting works have emerged which try to challenge and deconstruct this simplistic understanding of food self-provisioning in CEE (see e.g. Jehlička et al. 2020; Sovová 2020; Šiftová 2020). This paper aims to add to the recent surge in interest in the topic of food self-provisioning in Czechia. It does this by looking at some specific motivations and behaviours related to home food production in private home gardens.

\section{Data and method}

This research is based on data collected within a larger project on home gardens. The questionnaire survey included 462 home gardens in different settlement types in Czechia visited between April 2019 and November 2019. Gardeners were interviewed with a PAPI method (paper and pen interview) by the author and instructed graduate students of geography from the Faculty of Science, Charles University, Prague. Within each model location (selected by the author's expert knowledge taking into account the settlement size, housing type, and building density to represent the most typical examples of residential landscapes as far as possible), the interviewers used an availability sampling method (Reichel 2009). The gardeners who were present at home or directly in the garden were interviewed first. To reinforce the randomness of the sampling, interviewers approached every fifth 
house with a garden on a street within the model location. If an adult gardener was present and agreed to be interviewed, the interview occurred and the interviewer then moved down the street, visiting the next fifth house with a home garden. If an adult gardener was not present, the interviewer moved to the next house with a garden and the same process repeated.

A standardized questionnaire was used, starting with a short introduction followed by multiple choice questions, one open question, and respondents' sociodemographic characteristics - gender, age, education, occupation, household size, number of children (up to 15 years), and ownership form of the garden. The closed questions were followed by a list of possible responses, which had been formulated on the basis of previous work (Dunnett, Quasim 2000; Schupp, Sharp 2012). Gardeners were asked about activities usually performed in the home garden and if these activities included home food production they were asked about the motivation for this endeavour. The response items offered were: food from my own garden is healthier (than the one from a shop); food from my own garden is tastes better; by gardening I maintain physical activity, manual work; I try to save on the products bought in shops; it is my hobby; I like to learn new things. Each of these options was rated on a scale from one to five, with a higher score indicating greater importance. The open question focused on plants produced in the garden. Questions on the use of rainwater and use of agrochemicals followed (answers in the form yes-coded as 1 or no-coded as 0 ).

Finally, questions measuring environmental behaviour and economic hardship appeared. To answer the question on association between home food production and pro-environment behaviour, respondents were asked to identify how often in the last year they participated in the following environmental activities: watched a television special about the environment; recycled waste (paper, glass, plastics, cans, etc.); stopped buying a product associated with an environmental problem; used their own bags when shopping; donated money or volunteered for an environmental group; or attended a public demonstration on an environmental issue. These environmental behaviour related issues stem from the International Social Survey Program (ISSP), a continuing cross-national social scientific research program worldwide (www.issp.org), which has been used successfully in research of diverse issues related to society and environment. It allows good comparability for further analyses, since environmental problems have become increasingly global and individual around the world are exposed to similar messages (Hadler, Haller 2011, p. 316). The ISSP environment questions module has been shortened and modified, e.g. questions on viewing of TV specials about environment or using own bags when shopping were added to assess the Czech context (inspired also by Shupp, Sharp 2012). To assess economic hardship, respondents were asked whether in the last year they or other family members had to make any of the following adjustments: used savings to meet expenses; changed transportation patterns to save money; eaten at 
Table 1 - Basic characteristics of the sample

\begin{tabular}{lr}
\hline Gender & $\%$ \\
\hline men & 37.3 \\
women & 62.7 \\
\hline Age & \\
\hline up to 25 & 9.3 \\
$25-34$ & 13.6 \\
$35-44$ & 19.0 \\
$45-54$ & 25.5 \\
$55-64$ & 13.8 \\
$65+$ & 18.8 \\
\hline Household size & \\
\hline 1 & \\
2 & 5.2 \\
3 & 27.6 \\
4 & 20.1 \\
5 & 28.9 \\
$6+$ & 13.2 \\
\hline Children $<15$ & 5.0 \\
\hline 0 & \\
1 & \\
2 & 66.9 \\
$3+$ & 16.0 \\
\hline
\end{tabular}

\begin{tabular}{lr}
\hline Occupation & $\%$ \\
\hline top professionals & 5.2 \\
intermediary professionals & 23.5 \\
administrative support & 21.8 \\
skilled manual workers & 13.6 \\
unskilled manual workers & 3.9 \\
maternity leave & 3.2 \\
students & 7.5 \\
pensioners & 20.7 \\
unemployed & 0.6 \\
\hline Ownership & \\
\hline private & 93.1 \\
rented & 6.9 \\
\hline Settlement type* & \\
\hline large towns & 43.8 \\
small and medium-sized towns & 21.3 \\
rural areas and villages & 34.9 \\
\hline Size of the garden & \\
\hline up to $150 \mathrm{~m}^{2}$ & 21.8 \\
$151-400 \mathrm{~m}^{2}$ & 31.7 \\
$401-1,000 \mathrm{~m}^{2}$ & 35.9 \\
$1,001 \mathrm{~m}^{2}$ and more & 10.6 \\
\hline
\end{tabular}

Note: ${ }^{~}$ large towns (50,000 and more inhabitants); small and medium-sized towns (5,000-50,000 inhabitants); rural areas and villages (up to 5,000 inhabitants)

Source: author's own survey.

home or changed the types of food eaten to save money (Shupp, Sharp 2012). Answers were again coded (as yes or no, 1 or 0 respectively).

The basic characteristics of the sample are presented in Table 1. This sample is not, nor did aim to be, representative of the Czech population. It rather strived to represent the diversity of settlement types and neighbourhoods to collect the widest possible spectrum of practices and values found in home gardens.

The responses were analysed through a simple response analysis (Freeman et al. 2012), with simple frequency counts executed and basic descriptive statistics. For associations between gardening motivations, environmental and economic hardship scale, characteristics of gardens, and demographic variables, calculation of contingency coefficients (CC) were used. Only those relationships that were significant $(\mathrm{p}<0.05)$ and with significant residuals for some categories are discussed below. All the analyses were performed in SPSS statistical software ver. 20.0. 
Nevertheless, it is necessary to interpret the influence of some characteristics (gender, age, occupation, etc.) with caution and assign them rather supplementary role in the analysis, since these variables were compiled at the individual level of each respondent, while garden use and environmental and economic behaviour is without doubt a matter of the whole household.

\section{Results and discussion}

First, the activities performed in the home garden were analysed (Fig. 1). Not surprisingly, vegetable and herb production ranked first, which accords with the results of previous works aimed at quantification of food self-provisioning, declaring it as a traditional activity at a very high level in the Czechia (38\% of the Czech population according to Jehlička and Daněk 2017). The level of food self-provisioning in the Czechia is clearly outnumbering most countries of Western Europe (Alber, Kohler 2008; Church et al. 2015); nevertheless, the Australian experience shows that possibly almost $52 \%$ of households produce their food (Zainuddin, Mercer 2014) and about 31\% of U.S. households produce at least some food (Church et al. 2015). Passive relaxation scored second, followed by other gardening activities such as ornamental flower growing and fruit production. The role of active relaxation - in the form of manual work in the garden - was also often mentioned,

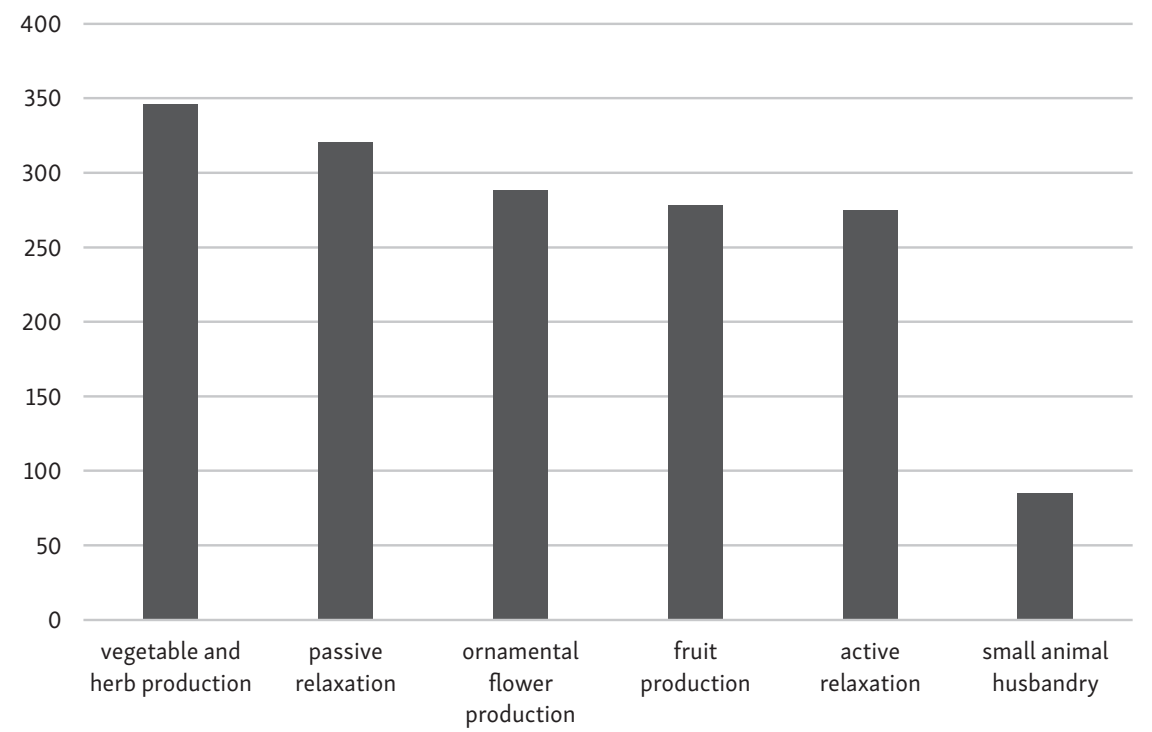

Fig. 1 - Functions of home gardens (total number of responses for a particular option in a multiplechoice question, $n=462$ ). Source: author's own survey. 


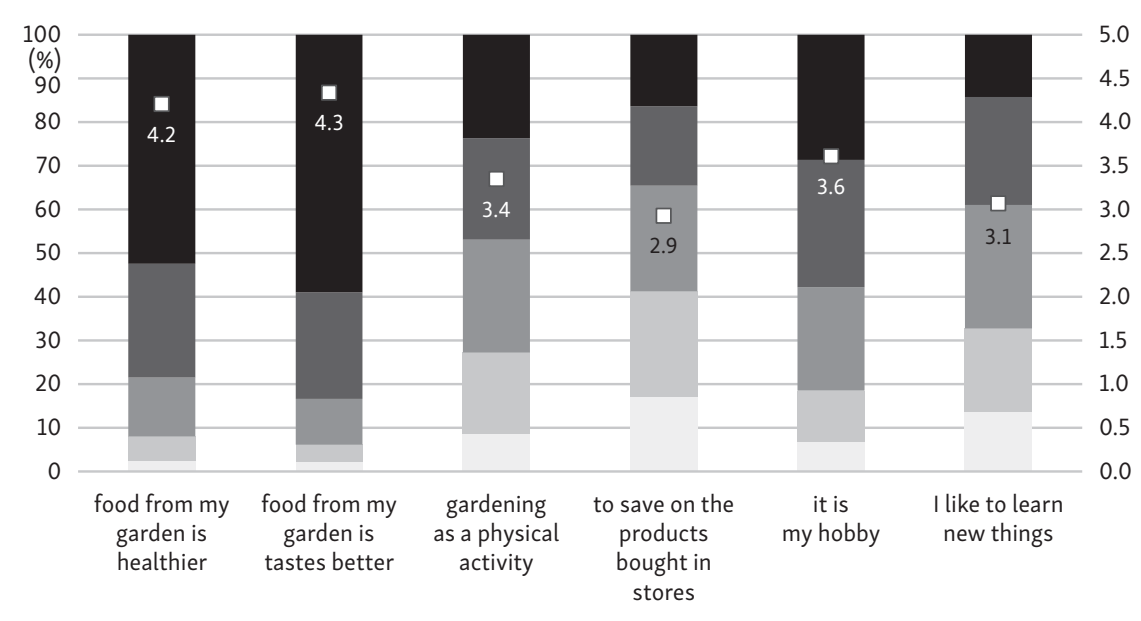

$1 \square 2 \square 3 \square 4 \square 5 \square$ mean score

Fig. 2 - Motivations for food self-provisioning in home gardens ( 1 - the least important, 5 - the most important). Source: author's own survey.

affirming the importance of gardening as a hobby among the Czech population (Sovová 2020, Vávra et al. 2018). Small animal husbandry was practiced by a small number of households in the sample. Gardens in the survey had often multiple functions. The most often mentioned combinations were these: passive relaxation + active relaxation + vegetable production + fruit production + ornamental flowers production ( 48 respondents); passive relaxation + vegetable production + fruit production + ornamental flowers (41 respondents) and active relaxation + vegetable production + fruit production + ornamental flowers (34 respondents).

Ninety-one per cent of the households approached in this survey produced some food in their home gardens. The most important motivation for food selfproduction in home gardens was the better taste of food produced in one's own garden, followed by the fact that gardeners view this food as healthier (Fig. 2). These two motivations were recognized as "very important" by more than half of the respondents. Gardening being a hobby was the third most important motivation, closely followed by the fact that gardening is a meaningful form of physical activity. Economic motivation reached the lowest mean score in the evaluation and the highest percentage of respondents $(17.1 \%)$ stated that this motivation is the least important. These results show the stable character of Czech food selfprovisioning practice, since they are compliant with the results of both the first surveys (Smith, Jehlička 2013) and more recent ones (Sovová 2020, Vávra et al. 2018) on FSP motivations, as well as with many foreign (Global North) studies (Clayton 2007; Kirkpatrick, Davison 2018; Kotright, Wakefield 2011; McClintock et al. 2016; Winkler, Maier, Lewandowski 2019 etc.). 
As regards the plants in the gardens and food production, not surprisingly a combination of diverse vegetables was the most frequent response (178); these combinations most often included tomatoes, potatoes, onions, lettuce, cabbages, garlic, and cucumbers. Some gardeners specialized in selected types of vegetables tomatoes were only planted by 46 respondents and bulbous vegetables (onion, garlic) only by 22 respondents. Fruit trees and shrubs represented the second most frequent category, mentioned by 133 gardeners. Herbs (mainly parsley, chives, oregano, basil, mint, and rosemary) were also very important (111) and fruit berries (101) represented another frequently mentioned category of produce (mainly strawberries, blackberries, currants, and raspberries). Other produce was markedly less often mentioned, such as nuts, grapes, hemp, figs, sea buckthorn, or goji.

These results accord to some extent with the results of respondents' food logs in the work of Sovová (2020) - mainly in the importance of some produce originating from gardens, such as tomatoes, berries, cucumber, lettuce, and cherries. The strong focus on tomatoes was also found in Kirkpatrick and Davison (2018) and Kotright and Wakefield (2011); all these studies confirm the perceived difference in the quality between the home-grown tomatoes and those bought in supermarket. In my study, there were obviously more respondents oriented to the planting of strawberries. In fact, the combination tomatoes - strawberries - herbs was the most common in my sample. Interestingly, the strong focus on herbs in our sample also differentiates the home gardens in my study from other types of gardens (e.g. allotments) researched in the above-mentioned study (Sovová 2020). Such similar emphasis on herb production was also confirmed in Kirkpatrick and Davison (2018, p. 31), who acknowledged salad and herb gardens as a new "fashion" reflecting the strength of new food culture biased towards products linked to social identity, distinction, and status (and displayed at dinner parties and family gatherings). A significant proportion of urban households in many wealthy societies are likely to be presently engaged in this activity.

As regards the use of rainwater and agrochemicals, the responses are depicted in Figure 3. Almost $83 \%$ of respondents in the sample use rainwater in their home garden and consider it as a common practice. This strongly corroborates the idea of quiet sustainability (Smith, Jehlička 2013), which implies that Czech home gardeners act environmentally friendly in an unconscious manner, automatically, without being necessarily concerned with environmental issues and activism. Cook, Hall, Larson (2012) state a slightly similar situation when conservation of outdoor water was not caused by price or environmental concerns but simply by the need to do so in context of regional water shortages.

Concerning agrochemicals, most of the respondents do not use them (65.8\%), but slightly more than one third of them admitted their use at least occasionally (34.2\%). Comparably, Vávra, Daněk, and Jehlička (2018) found that Czech self-provisioners produce their food in a rather environmentally friendly way. According 

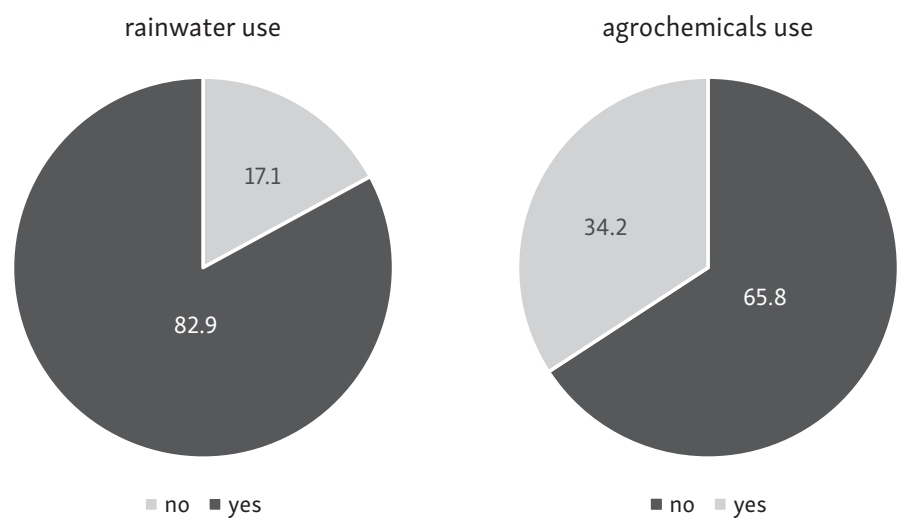

Fig. 3 - The use of rainwater and agrochemicals in home gardens. Source: author's own survey.

to their study, $17 \%$ of gardeners did not use any fertilisers, $44 \%$ used only organic fertilisers (compost, manure), 33\% used both organic and industrial, and only $6 \%$ relied on industrial fertilisers only. Also, Sovová (2020) admits that agrochemicals had very negative connotations among her respondents and most of them tried to avoid them, or avoid the plants that are known to be susceptible to pests, etc. However, in some cases, even her respondents admitted that for particular kinds of produce, the use of chemicals is necessary, or precisely a "necessary evil" (Sovová 2020, p. 117). Similarly, Kotright and Wakefield (2011, p. 48) found that most of their Canadian respondents used only organic methods on their gardens, and even those who did use some pesticides in their garden did not use them on their food crops. Still, Sovová and Veen (2020) in their comparative study highlight that the Dutch determination to produce food in an organic way as much as possible was the only important difference between Czech and Dutch food self-provisioners.

Compared to previous works, relation to the environmental behaviour of surveyed households and potential environmental change was one of the new features included in this survey. The responses to the questions on environmental behaviour are shown in Figure 4. The vast majority of respondents regularly separate their waste for recycling. In this sample it is even more than the national average, which is $73 \%$ of Czechs who regularly separate their waste (Samosebou 2021). The majority of respondents also use their own bags when shopping. More than two thirds also admitted that they watch environmental programmes on TV. Slightly more than a third of respondents have stopped buying certain products which could be associated with an environmental problem (such as meat or palm oil), this could be at least partially explained by the fact that among Czechs, according to de Groot and Steg (2007), the egoistic value orientation made a significant contribution to the explanation of personal norms in environmental behaviour and for many people it might be hard to relate to an environmental concern which is 


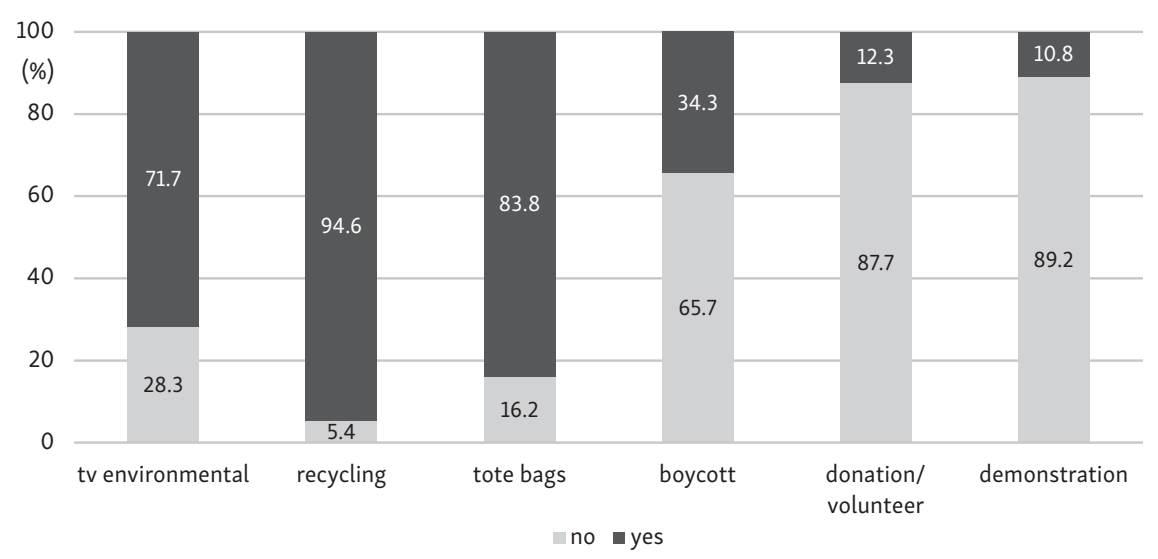

Fig. 4 - Responses to environmental behaviour questions. Source: author's own survey.

not exactly "local" (Grinstein, Riefler 2015). Finally, 12.3\% of respondents donated money or volunteered for an environmental group or organization, and $10.8 \%$ attended a public demonstration to express their dissatisfaction with an environmental issue. These forms of public environmental behaviour (Stern 2000) are not typical for the Czech society, as results also from diverse comparative studies (Hadler, Haller 2011; Morren, Grinstein 2016).

A positive relationship between pro-environment behaviour and practice of home gardening was identified in Schupp and Sharp (2012). However, there are other works which document that there is not a simple link between gardening and people's concern with the environment (e.g. Bhatti, Church 2004). In the Czech case, the situation shows rather an ambivalent result. Obviously Czechs are active and environmentally conscious when it comes to private (or individual) environmental behaviour, such as recycling (recycling bins are widely available and accessible, educational campaigns quite ample), using their own tote bags when shopping, or become aware by watching the environmental specials on TV. In general, our results affirm those of Krajhanzl, Chabada and Svobodová (2018), who claim that in terms of pro-environmental behaviour, Czechs are active mainly in waste sorting, while much less involved in other areas. They unambiguously think that the government and state should resolve the environmental problems, not the people, and they are not very willing to pay to support nature conservation and environmental protection (Krajhanzl, Chabada, Svobodová 2018, pp. 348-349).

When it comes to public (or collective) behaviour, the results of this paper also document that the participation and ardour decreases. This might, however, be a heritage of a long period of suppression of civic rights and freedom of voicing one's ideas and values during the era of communism. This left little or no tradition of civic engagement and, as Spilková (2017, p. 895) states, establishment of market 
mechanisms after the revolution of 1989 and transition to a democratic society in the nineties of $20^{\text {th }}$ century first led to a focus on the fulfilment on individual needs in the majority of citizens. As Lehnert et al. (2020, p. 865) "Czechia has suffered a certain delay in the engagement of society with environmental issues and in the development of pro-environmental behaviour both public and private". Thus, until recently, there was no fertile ground for community or societally engaged actions, either for politics, human rights, or environmental problems. Yet, this might change rapidly, since social movements (including environmental activism) and democratization are closely related (Tilly 2004; Hadler, Haller 2011).

Certainly, a different situation is revealed in the case of economic hardship scale. The responses to the economic hardship questions are presented in Figure 5. Most of the respondents and their family members did not have to make any of the adjustments mentioned, although almost a quarter of the respondents did use their savings to meet their expenses in the last year, $17.1 \%$ reported eating at home more or changing some foods they usually consume to save money, and $12.1 \%$ admitted a change in their transportation patterns to save money. Thus, the results of this study also confirm that Czech are not overly motivated by economic reason while producing their home food. On the other hand, it is obvious that some of the Czech households might experience some economic issues (stronger motivation to save money by food self-provisioning for the oldest respondents $65+, \mathrm{CC}=0.281, \mathrm{p}<.05$ and pensioners, $\mathrm{CC}=0.343, \mathrm{p}<.05$ ); and savings were frequently also mentioned in the work of Smith and Jehlička (2013) and Jehlička and Daněk (2017). Obviously, the subsequent analysis showed that the motivation to save money while producing home food relates to the group of respondents who

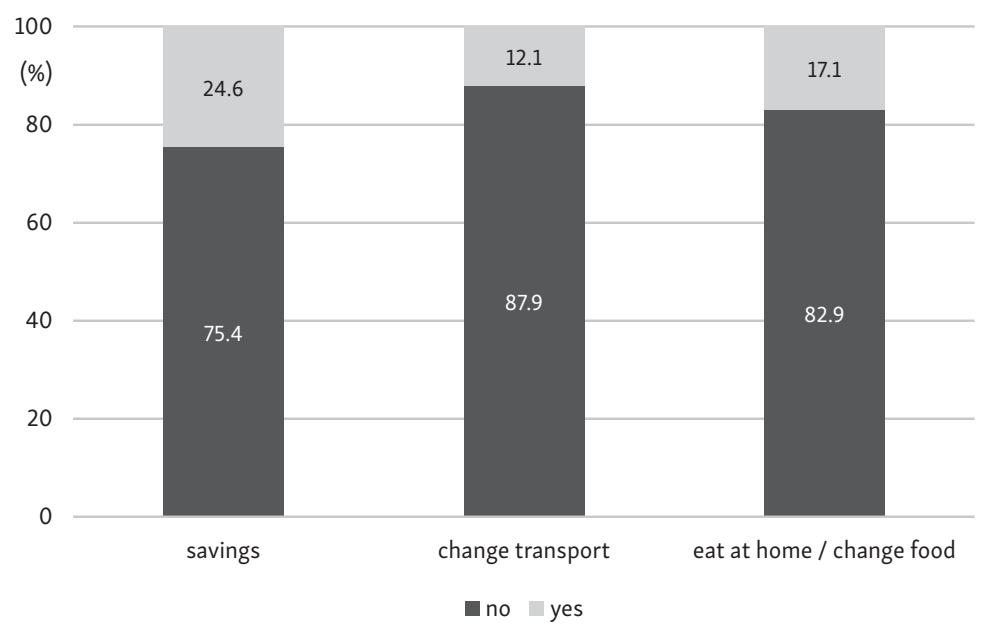

Fig. 5 - Responses to economic hardship questions. Source: author's own survey. 
had to eat mostly at home or change food habits to save $(C C=0.216, p<.001)$. In this regard, it is opportune that the orientation of a home garden may temporarily or permanently change - from lawns and flowers when there is enough money in the household, to a productive garden in times of crisis or shortage (Niňez 1984).

Most of the associations between demographic characteristics and the motivations for home food production were rather weak or insignificant; this also relates to the limitation mentioned above - gardening is the matter of the whole family. However, the survey was completed by one representative only, presenting his/her characteristics. Nevertheless, among the significant associations found there was slightly lesser importance attributed to the healthiness of home food by men $(C C=0.173, p<.05)$; men also tend to separate waste recycle less than women $(C C=0.130, p<.05)$ and use their own bags less when shopping $(C C=0.144$, $\mathrm{p}<.05$ ). The fact that both men and women are involved in the care of the home garden, but usually in different tasks, roles, and with different approach, has been already mentioned in many studies (Agrawal 2003; Chambers, Momsen 2007; Reyes-García et al. 2010; Vogl-Lukasser et al. 2010 etc.) and women usually score as more engaged in environment protection, biodiversity preservation, and nutrition and health care for the family members (Mattalia, Calvo, Migliorini 2018).

The results of this survey also reveal significantly higher importance of gardening as a physical activity for the age groups of 55-64 and 64+ years (CC $=0.337$, $\mathrm{p}<.001$ ) and for the occupational group pensioners $(C C=0.363, \mathrm{p}<.001)$; stronger importance in gardening as a hobby for the age groups of 55-64 and 64+ years ( $C C=0.336, p<.001)$ and pensioners; on the other hand, it was the least important motivation among intermediary professionals $(C C=0.363, p<.05)$. This finding is again in accordance with previous Czech studies (Smith, Jehlička 2013; Sovová 2020) which found higher integration of food self-provisioning into the lives of older people since it does not have to compete with paid jobs and similar obligations. Gardening and food production is an important, often full-day activity for retired people, enabling them to establish a routine and plan day-to-day activities, while at the same time expressing their identity and independence (Bhatti 2006).

Dunnett and Qasim (2000) state that 64\% of their respondents (55 and older) considered gardening to be good exercise for them, whereas younger respondents tended not to value the opportunity for exercise. This clearly shows the "competition of hobbies" also discovered in this study. Here, the youngest respondents tend to watch significantly less environmental specials on TV $(C C=0.293, p<.001)$. Pensioners tend to watch the TV more often, whereas those who are the least probable to watch the environmental programmes on TV were the top professionals, mothers on maternity leave, and students. Those in the biggest towns tended to watch environmental TV specials the least $(C C=0.142, \mathrm{p}<.05)$. Logically, those who tend to watch TV less were those who like gardening as a physical activity the most $(C C=0.202, p<.001)$, and those who have gardening as a hobby $(C C=0.228$, 
$\mathrm{p}<.001)$ and those who learn new things $(\mathrm{CC}=0.256, \mathrm{p}<.001)$. These results just declare that gardening may often compete with other hobbies (Kotright, Wakefield 2011; Sovová 2020; Spilková, Rypáčková 2019), mainly in the case of younger respondents and also among those living in towns, which offer a lots of exciting opportunities for leisure. Under the time constraints of modern living, one has to negotiate competing hobbies and activities and it was clearly the group of pensioners who come out as the most time-affluent and thus winning in the case of gardening.

Last but not least, in this study, young people between 25-34 and the gardeners who like to learn new things are significantly more active in public demonstrations ( $C C=0.198, p<.05 ; C C=0.232, p<.001$, respectively) and the same is true for occupational group students $(C C=0.194, p<.05)$. Also, not surprisingly, those who boycotted some products during the last year are those who are motivated by healthier food ( $C C=0.229, p<.001)$, tastier food $(C C=0.230, p<.001)$, physical activity while gardening $(\mathrm{CC}=0.172, \mathrm{p}<.05)$, and learning new things by gardening $(C C=0.204, p<.001)$. Again, these results resonate with the results of, for example, Sovová and Veen $(2020$, p. 11) who declared that for most of their respondents, home food production was not performed as an activist endeavour, and their motivations were mainly to enjoy gardening, be outdoors, and have access to fresh home-grown produce. On the other hand, there is an indication of a possible turn to a more active approach in the results of this study - mainly in the connection of younger age, political activization in public demonstrations, and motivation to change the food system into a more sustainable one. Similar associations can also be found for environmental and political values in Whitmarsh (2011) or for a certain importance assigned to an identity of organic gardener or permaculturalist (McClintock et al. 2016).

\section{Conclusions}

This paper aimed to revisit the motivations of Czech gardeners for their involvement in food self-provisioning, focusing on home gardens as the most widespread, yet less studied type of gardens. It showed that production of vegetables and herbs is still the prevailing function of Czech home gardens. It also validated the results of previous studies on Czech food self-provisioning by reasserting the motivations for this activity - better taste and healthier way of production and enjoyment of gardening as a hobby. These motivations remain mostly intact during societal transformations or economy fluctuations over recent decades, which also declares the strength and tradition of home food production in Czechia. By focusing on health and taste, people express a desire to control what they eat, and by pronouncing food production in gardens as a hobby, they reveal satisfaction in nurturing 
plants to harvest. Economic motivation is regularly downplayed as an important motivation in most of the works focusing on Czech food self-provisioning. It was the least important reason also in the study presented, however still important for almost one third of gardeners. Moreover, although there was evidence for some kinds of pro-environment behaviour, this is limited to rather inconspicuous and "unobtrusive" private actions, such as waste separation for recycling or using one's own bags when shopping.

This paper also affirms an undeniable tradition and stability of gardening in Czechia. However, currently, gardening is significantly more enjoyed by pensioners and the elderly, who enjoy it as a truly multifaceted act of resistance to aging, since it clearly contributes to their widely conceived physical and mental health. The middle-aged (35-55) and their responses clearly show that competing duties, but also competing leisure activities and thus less time to care for the garden, can be a crucial barrier to food gardening. It is thus the young generation who apparently is becoming the successor in the gardening and self-provisioning tradition, often aiming to do it differently to the generation of their grand-parents - e.g. in the forms of community gardening, or as organic gardeners or permaculturalists. They also present hope for a more sustainable food system in general since they seem to be not only more interested in learning new things in their gardening practice, but also gathering relevant information, questioning diverse claims, interrogating evidence, and voicing their opinions and values. As a suggestion for the future research agenda, I see a connection between food self-provisioning and participation in the local food system as a logical next step in the examination related to home food production.

\section{References}

AGRAWAL, A. (2003): Sustainable governance of common-pool resources: context, methods, and politics. Annual Review of Anthropology, 32, October, 243-262.

ALBER, J., KOHLER, U. (2008): Informal food production in the enlarged European Union. Social Indicators Research, 89, 1, 113-127.

BHATTI, M. (2006): "When I'm in the garden I can create my own paradise": Homes and gardens in later life. The Sociological Review, 54, 2, 318-341.

BHATTI, M., CHURCH, A. (2004): Home, the culture of nature and meanings of gardens in late modernity. Housing Studies, 19, 1, 37-51.

CHAMBERS, K.J., MOMSEN, J.H. (2007): From the kitchen and the field: gender and maize diversity in the Bajo region of Mexico. Singapore Journal of Tropical Geography, 28, 1, 39-56.

CHURCH, A., MITCHELL, R., RAVENSCROFT, N., STAPLETON, L.M. (2015): 'Growing your own': A multi-level modelling approach to understanding personal food growing trends and motivations in Europe. Ecological Economics, 110, February, 71-80.

CLAYTON, S. (2007): Domesticated nature: Motivations for gardening and perceptions of environmental impact. Journal of Environmental Psychology, 27, 3, 215-224. 
COOK, E.M., HALL, S.J., LARSON, K.L. (2012): Residential landscapes as social-ecological systems: a synthesis of multi-scalar interactions between people and their home environment. Urban Ecosystems, 15, 1, 19-52.

DE GROOT, J.I.M., STEG, L. (2007): Value orientations and environmental beliefs in five countries. Journal of Cross-Cultural Psychology, 38, 3, 318-332.

DUBOVÁ, L., MACHÁČ, J., VACKOVÁ, A. (2020): Food provision, social interaction or relaxation: Which drivers are vital to being a member of community gardens in Czech cities? Sustainability, 12, 22, 9588.

DUNNETT, N., QASIM, M. (2000): Perceived benefits to human well-being of urban gardens. Horticultural Technology, 10, 1, 40-45.

FREEMAN, C., DICKINSON, K.J.M., PORTER, S., VAN HEEZIK, Y. (2012): "My garden is an expression of me": Exploring householders' relationships with their gardens. Journal of Environmental Psychology, 32, 2, 135-143.

GIBAS, P., MATĚJOVSKÁ, L., NOVÁK, A., ROLFOVÁ, E., TVARDKOVÁ, V., VALEŠOVÁ, I., VESELÝ, M. (2013): Zahrádkové osady: Stíny minulosti, nebo záblesky budoucnosti? Charles University, Prague.

GRINSTEIN, A., RIEFLER, P. (2015): Citizens of the (green) world? Cosmopolitan orientation and sustainability. Journal of International Business Studies, 46, 694-715.

HADLER, M., HALLER, M. (2011): Global activism and nationally driven recycling: The influence of world society and national contexts on public and private environmental behavior. International Sociology, 26, 3, 315-345.

JANKOVIČOVÁ, Z. (2017): Nenechte si ujít největší zahrádkářskou událost desetiletí. http:// www.zahradkari.cz/europom/ (25.2.2021).

JEHLIČKA, P., DANĚK, P. (2017): Rendering the Actually Existing Sharing Economy Visible: Home-Grown Food and the Pleasure of Sharing. Sociologia Ruralis, 57, 3, 274-296.

JEHLIČKA, P., DANĚK, P., VÁVRA, J. (2019): Rethinking resilience: home gardening, food sharing and everyday resistance. Canadian Journal of Development Studies, 40, 4, 511-527.

JEHLIČKA, P., GRIVINS, M., VISSER, O., BALÁZS, B. (2020): Thinking food like an East European: A critical reflection on the framing of food systems. Journal of Rural Studies, 76, May, 286-295.

JEHLIČKA, P., KOSTELECKÝ, T., SMITH, J. (2013): Food self-provisioning in Czechia: Beyond coping strategy of the poor: A response to Alber and Kohler's 'informal food production in the Enlarged European Union'(2008). Social Indicators Research, 111, 1, 219-234.

KIRKPATRICK, J.B., DAVISON, A. (2018): Home-grown: Gardens, practices and motivations in urban domestic vegetable production. Landscape and Urban Planning, 170, February, 24-33.

KOTRIGHT, R., WAKEFIELD, S. (2011): Edible backyards: a qualitative study of household food growing and its contributions to food security. Agriculture and Human Values, 28, 1, 39-53.

KRAJHANZL, J., CHABADA, T., SVOBODOVÁ, R. (2018): Vztah české veřejnosti k př́rodě a životnímu prostředí. Masarykova Univerzita, Brno.

LARDER, N., LYONS, K., WOOLCOCK, G. (2014): Enacting food sovereignty: values and meanings in the act of domestic food production in urban Australia. Local Environment, 19, 1, $56-76$.

LEHNERT, M., FIEDOR, D., FRAJER, J., HERCIK, J., JUREK, M. (2020): Czech students and mitigation of global warming. Environmental Education Research, 26, 6, 864-889.

LORAM, A., WARREN, P.H., GASTON, K.J. (2008): Urban domestic gardens (XIV): the characteristics of gardens in five cities. Environmental Management, 42, 3, 361.

MACL, O. (1999): Zahrádkářské hnutí - kořeny, tradice, vývoj. ÚR ČZS, Hradec Králové. 
MACL, O. (2002): Zahrádkářské hnutí: Etapy vývoje, zakladatelé, vznik v regionech. ÚR ČZS, Hradec Králové.

MATTALIA, G., CALVO, A., MIGLIORINI, P. (2018): Alpine home gardens in the Western Italian Alps: the role of gender on the local agro-biodiversity and its management. Biodiversity, 19, 3-4, 179-187.

McCLINTOCK, N., MAHMOUDI, D., SIMPSON, M., SANTOS PEREIRA, J. (2016): Socio-spatial differentiation in the Sustainable City: A mixed-methods assessment of residential gardens in metropolitan Portland, Oregon, USA. Landscape and Urban Planning, 148, April, 1-16.

MORREN, M., GRINSTEIN, A. (2016): Explaining environmental behavior across borders: A meta-analysis. Journal of Environmental Psychology, 47, September, 91-106.

NIŇEZ, V.K. (1984): Household Gardens: Theoretical Considerations on an Old Survival Strategy. Potatoes in Food Systems Research Series. Report no. 1. Washington, D.C., U.S. Agency for International Development, https://pdf.usaid.gov/pdf_docs/PNAAS307.pdf (8.12. 2020).

REICHEL, J. (2009): Kapitoly metodologie sociálních výzkumů. Grada Publishing, Prague.

REYES-GARCÍA, V., VILA, S., ACEITUNO-MATA, L., CALVET-MIR, L., GARANATJE, T., JESCH, A., VALLLÉS, J. (2010): Gendered homegardens: a study in three mountain areas of the Iberian Peninsula. Economic Botany, 64, 3, 235-247.

SAMOSEBOU (2021): Kolik odpadu vyprodukuje průměrně každý Čech? https://www.samosebou.cz/2020/05/13/vysledky-trideni-a-recyklace-odpadu-za-rok-2019/ (25. 2. 2021).

SCHUPP, J., SHARP, J. (2012): Exploring the social bases of home gardening. Agriculture and Human Values, 29,1, 93-105.

SMITH, J., JEHLIČKA, P. (2013): Quiet sustainability: Fertile lessons from Europe's productive gardeners. Journal of Rural Studies, 32, October, 148-157.

SOVOVÁ, L. (2015): Self-provisioning, sustainability and environmental consciousness in Brno Allotment Gardens. Sociální Studia 12, 3, 11-26.

SOVOVÁ, L. (2020): Grow, share or buy? Understanding the diverse food economies of urban gardeners. Ph.D. Thesis. Masaryk University, Brno.

SOVOVÁ, L., VEEN, E.J. (2020): Neither poor nor cool: Practising food self-provisioning in allotment gardens in the Netherlands and Czechia. Sustainability, 12, 12, 5134.

SPILKOVÁ, J. (2017): Producing space, cultivating community: the story of Prague's new community gardens. Agriculture and Human Values, 34, 4, 887-897.

SPILKOVÁ, J., RYPÁČKOVÁ, P. (2019): Prague's community gardening in liquid times: challenges in the creation of spaces for social connection. Leisure Studies, 38, 4, 468-479.

SPILKOVÁ, J., VÁGNER, J. (2016): The loss of land devoted to allotment gardening: The context of the contrasting pressures of urban planning, public and private interests in Prague, Czechia. Land Use Policy, 52, March, 232-239.

SPILKOVÁ, J., VÁGNER, J. (2018): Food gardens as important elements of urban agriculture: Spatio-developmental trends and future prospects for urban gardening in Czechia. Norsk Geografisk Tidsskrift-Norwegian Journal of Geography, 72, 1, 1-12.

STERN, P.C. (2000): New environmental theories: Toward a coherent theory of environmentally significant behavior. Social Issues, 56, 3, 407-424.

ŠIFTOVÁ, J. (2020): Foraging in Czechia: The nation's precious hobby. Norsk Geografisk Tidsskrift-Norwegian Journal of Geography, 74, 5, 310-320.

TILLY, C. (2004): Social Movements, 1768-2004. Paradigm Publishers, Boulder, CO.

VÁVRA, J., DANĚK, P., JEHLIČKA, P. (2018): What is the contribution of food self-provisioning towards environmental sustainability? A case study of active gardeners. Journal of Cleaner Production, 185, June, 1015-1023. 
VÁVRA, J., MEGYESI, B., DUŽÍ, B., CRAIG, T., KLUFOVÁ, R., LAPKA, M., CUDLÍNOVÁ, E. (2018): Food self-provisioning in Europe: an exploration of sociodemographic factors in five regions. Rural Sociology, 83, 2, 431-461.

VÁVRA, J., SMUTNÁ, Z., HRUŠKA, V. (2021): Why I would want to live in the village I I was not interested in cultivating the plot? A study of home gardening in rural Czechia. Sustainability, $13,706$.

VOGL-LUKASSER, B., VOGL, C.R., GÜTLER, M., HECKLER, S. (2010): Plant species with spontaneous reproduction in homegardens in Eastern Tyrol (Austria): Perception and management by women farmers. Ethnobotany Research and Applications, 8, 1-15.

WHITMARSH, L. (2011): Scepticism and uncertainty about climate change: Dimensions, determinants and change over time. Global Environmental Change 21, 2, 690-700.

WINKLER, B., MAIER, A., LEWANDOWSKI, I. (2019): Urban gardening in Germany: cultivating a sustainable lifestyle for the societal transition to a bioeconomy. Sustainability, 11, 3, 801 .

ZAINUDDIN, Z., MERCER, D. (2014): Domestic Residential Garden Food Production in Melbourne, Australia: a fine-grained analysis and pilot study. Australian Geographer, 45, $4,465-484$.

\section{ACKNOWLEDGMENTS}

This work was supported by the Czech Science Foundation under grant number 17-03796S "Food and the city: The geography of urban agriculture in the Czech context".

\section{ORCID}

JANA ŠIFTOVÁ

https://orcid.org/0000-0002-9117-0878 